\title{
PERUBAHAN RASIONALISASI MORAL TINDAKAN AGRESI PADA MANTAN NARAPIDANA TERORIS DI INDONESIA (STUDI KASUS)
}

\author{
Diana Baso Limbu'. Berta Esti Ari Prasetya ${ }^{2}$ \\ Fakultas Psikologi Universitas Kristen Satya Wacana, Salatiga ${ }^{1,2}$ \\ Email:1802015151@student.uksw.edu.2berta.prasetya@uksw.edu.
}

\begin{abstract}
Abstrak
Penelitian ini bertujuan untuk menggambarkan bagaimana perubahan rasionalisasi moral tindakan agresi pada mantan narapidana teroris serta apa saja hal hal pendorong perubahan tersebut. Penelitian ini menggunakan pendekatan kualitatif yaitu studi kasus. Informasi utama dalam penelitian ini adalah seorang mantan teroris yang pernah terlibat aktif dalam pelatihan militer dan perang di Filipina Selatan serta terlibat kasus penyimpanan bom Semarang (Sri Redjeki). Data dianalisis dengan menggunakan teknik analisis model Milles dan Hebermen (1992), yakni mereduksi data, penyajian data hingga penarikan kesimpulan yang diambil dari hasil wawancara mendalam. Penelitian ini dianalisis dengan memperhatikan teori Tsang (2002) mengenai rasionalisasi moral serta teori Bandura (1991); Bandura, Barbaranelli, Ceprara, dan Pastorelli (1996), mengenai moral disengagement (pelepasan moral) pada subjek ditunjukkan adanya perubahan justifikasi moral, penggunaan penghalusan istilah, perbandingan menguntungkan, mengabaikan konsekuensi, dan menyalahkan orang serta yang menjadi hal-hal pendorong perubahan rasionalisasi moral yaitu pengalaman, peran keluarga, adanya kesibukan/konsentrasi usaha, peran agama, keinginan hidup bermakna, dan peran personal.
\end{abstract}

Kata kunci: Terorisme, Perubahan Rasionalisasi Moral, Hal-Hal Pendorong Perubahan Rasionalisasi Moral.

\begin{abstract}
This study aims to describe how the moral rationalization of acts of aggression in former terrorist prisoners and what are the things driving these changes. This research uses a qualitative approach, which is a case study. The main informant in this study was a former terrorist who had been actively involved in military training and war in the southern Philippines and was involved in the Semarang (Sri Redjeki) bomb storage case. Data were analyzed using Milles and Hebermen (1992) model analysis techniques, namely reducing data, presenting data to drawing conclusions drawn from in-depth interviews. This research is analyzed by paying attention to Tsang's theory (2002) regarding moral rationalization and Bandura's theory, (1991); Bandura, Barbaranelli, Ceprara, and Pastorelli (1996) concerning moral disengagement. The results of this study found a change in moral rationalization on the subject indicated changes in moral justification, euphemistic labeling, advantageous comparison, distortion of consequences, and blaming the victim as well as the things that are driving the change in moral rationalization, namely experience, the role of the family, the presence of busyness / business concentration, the role of religion, the meaning of a meaningful life, and personal roles.
\end{abstract}

Keywords: Terrorism, Changes In Moral Rationalization, Things That Drive Changes In Moral Rationalization.

\section{PENDAHULUAN}

Memberantas kejahatan dengan tindakan kekerasan tidak akan membuat kejahatan itu berhenti (More; (dalam Hendrojono, 2005)). Begitu juga dalam konteks pemberantasan terorisme. Salah satu faktor yang mendasari gerakan terorisme adalah faham keagamaan yang radikal. Radikalisasi pada dasarnya istilah untuk menggambarkan adanya proses seseorang melakukan transformasi pemikiran dan pemahaman atas kondisi normal masyarakat menuju kondisi yang tidak normal, yaitu pembolehan melakukan tindakan kekerasan. Ketidaknormalan (irasionalitas) aksi 
terorisme dengan adanya aksi kekerasan yang berujung sampai pembunuhan atas nama membela Tuhan dianggap sebagai tindakan immoral (berdosa), sedangkan Tuhan adalah sumber moralitas (kebaikan). Dengan demikian, salah satu cara yang digunakan dalam memerangi terorisme yaitu adanya deradikalisasi.

Golose (2009), menyebutkan deradikalisasi merupakan segala upaya untuk menetralisir paham-paham radikal melalui pendekatan interdisipliner, seperti hukum, psikologi, agama dan sosial budaya bagi mereka yang dipengaruhi paham radikal atau pro kekerasan. Berkaitan proses radikalisasi adalah proses pemahaman atau pola pikir yang mengesahkan adanya pemberlakuan aksi kekerasan dalam artian hal tersebut berkaitan dengan rasionalisasi.

Perubahan rasionalisasi dapat terjadi melalui moral disengagement. Bandura, Caprara, Barbaranelli, Pastorelli, dan Regalia (2002), menyatakan bahwa disengangement moral atau pelepasan moral merupakan seseorang berperilaku berdasarkan standar moral yang ia bentuk melalui sistem regulasi diri. Regulasi diri rentan terhadap disengagement sehingga mengakibatkan seseorang dapat melakukan tindakan yang tidak sesuasi dengan standar moralnya. Serupa dengan Tsang (2002) menuliskan tentang rasionalisasi moral dimana seseorang mampu menginterpretasikan ulang perilaku immoral yang dilakukan sebagai tindakkan bermoral. Tsang menyimpulkan bahwa rasionalisasi moral memiliki peran sangat penting mengapa akhirnya seseorang berani dan bersedia melakukan kejahatan. Namun rasionalisasi moral juga berperan penting pada perubahan seseorang yang memilih meninggalkan jalan kekerasan, karena rasionalisasi moral berkaitan dengan faktor situasi dan faktor psikologis.

Berdasarkan teori Tsang dan Bandura, dkk (2002), mengenai rasionalisasi moral dan moral disengagement dengan enam mekanismenya yaitu justifikasi moral dimana individu melakukan tindakan buruk kepada orang lain, tetapi proses melakukan tindakan tersebut tampak dibenarkan secara moral, penghalusan istilah yaitu penggunaan suatu bahasa netral secara moral untuk membuat suatu perilaku buruk menjadi suatu perilaku yang terlihat tidak terlalu buruk, bahkan terlihat baik,

perbandingan

menguntungkan dimana sikap seseorang yang tidak etis akan berbahaya bila dibandingkan dengan sebuah perilaku etis. Sehingga, membuat sikap aslinya yang muncul dapat diterima, mendistorsi konsekuensi selalu menggampangkan 
atau tidak memperdulikan konsekuensi atau resiko dari apa yang telah dilakukan meskipun tarafnya kecil, dehumanisasi seseorang yang tidak menganggap orang lain seperti pada manusia umumnya, serta menyalahkan orang yaitu seseorang yang bersikap diri dengan menempatkan kesalahan atas perilaku yang dia lakukan kepada orang lain , maka fokus penelitian ini adalah perubahan rasionalisasi moral tindakan agresi pada mantan narapidana teroris di Indonesia. Melihat kedua teori tersebut berperan pada perubahan individu dari orang biasa menjadi berani dan bersedia melakukan tindakan ekstrim. Adapaun pertanyaan masalah dalam penelitian ini yaitu; pertama, bagaimana perubahan rasionalisasi tindakan agresi dari teroris menjadi mantan teroris di Indonesia?. Kedua, apa saja hal-hal pendorong pada proses perubahan rasionalisasi tindakan agresi dari teroris menjadi mantan teroris di Indonesia?

\section{METODE PENELITIAN}

Pada penelitian ini digunakan metode dengan pendekatan kualitatif. Metode penelitian yang digunakan yakni penelitian studi kasus (case study). Penelitian ini bertujuan untuk mengetahui perubahan rasionalisasi tindakan agresi pada mantan teroris.

Metode analisis data yang digunakan adalah analisis model Milles dan Hebermen (1992), analisis data meliputi tiga alur kegiatan, yakni; pertama, reduksi data. Kedua, penyajian data. Ketiga, penarikan kesimpulan adalah kegiatan penggambaran secara utuh dari obyek yang diteliti.

Subyek Penelitian. Dalam penelitian ini sampling menggunakan sampel bertujuan (purposive sampling), yaitu pengambilan sampel sumber data dengan pertimbangan tertentu. Penelitian ini melibatkan 1 partisipan yang merupakan mantan narapidana teroris, bergabung bersama kelompok Jemaah Islamiah (JI) kemudian bergabung dalam Moro Islamic Liberation di Filipina Selatan dan terlibat aktif pelatihan militer dan aksi perang di Filipina Selatan sejak tahun 2000 hingga 2002. Pada tahun 2002 kembali ke Indonesia dan pada tahun 2003 tertangkap karena kasus penyimpanan bom Semarang (Sri Redjeki). Tahun 2009 bebas bersyarat dan wajib lapor. Sejak tahun 2010 hingga sekarang Y tidak lagi terlibat dalam kelompok jaringan.

\section{Teknik Pengumpulan Data}

Dalam penelitian ini, metode pengumpulan data yang digunakan yaitu wawancara. Banister (dalam Poerwandari, 1998) menjelaskan bahwa wawancara kualitatif dilakukan bila peneliti bermaksud untuk memperoleh pengetahuan tentang makna-makna yang 
subyektif yang dipahami individu yang berkenaan dengan topik yang diteliti dan bermaksud melakukan eksplorasi terhadap isu tersebut, suatu hal yang tidak dapat dilakukan melalui pendekatan lain.

\section{HASIL DAN PEMBAHASAN}

\section{Perubahan Rasionalisasi Moral}

\section{a. Justifikasi moral}

Berdasarkan hasil data yang diperoleh, Y memang melakukan justifikasi moral. Y setuju bahwa perilaku atau aksi yang ia lakukan bukan sesuatu yang salah. Subjek pun membenarkan perilaku atau aksi yang ia lakukan dengan alasan bahwa ia melawan orang sepadan bukan warga sipil. Berikut kutipan percakapan sebelum keluar jaringan:

\begin{abstract}
Y: "Saya melawan karena yang saya lawan Tentara, bukan masyarakat Sipil, jadi mereka yang menggunakan teng, menggunakan roket, menggunakan senjata, saya juga sama, termasuk menggunakan pesawat. Jadi bagi saya waktu itu, inilah saatnya, yah kalo gagah tentara lawan tentara dong bukan melawan masyarakat Kota, sipil, halte, kalo yang di Surabaya, kampung melayu, Tamrin, kafe, Starbucks. Jadi saya menganggap masih menganggap yang berhak untuk kita lawan yah Tentara yang melakukan Agresi atau yang kita melawan orang yang sepadan"
\end{abstract}

Adapun saat ini, setelah keluar dari jaringan $\mathrm{Y}$ memiliki perubahan pandangan mengenai justifikasi nya yang berhak dianggap musuh dan berhak dibunuh, seperti tentara menjadi musuh ketika memerangi mereka, perasaan benci terhadap pengeboman yang dilakukan
Amerika serta menganggap bahwa Amerika juga merupakan bagian ciptaan Allah. Dari hasil tersebut dapat terlihat perubahan rasionalisasi dari sebelum dan sesudah keluar jaringan.

Y: “Kalo sekarang menjadi musuh ketika
mereka memerangi. Jadi ketika TNI kita
ngajakin silahturahmi, outbond bersama,
ya bukan musuh dong, Tapi jika tentara
Amerika selalu melakukan pengeboman
kami benci tentang pengeboman itu.(..)
jadi gak seperti dulu, kalo dulu Tentara
musuh, polisi bunuh. Sekarang sudah
berbeda. Kemudian saya juga punya
keyakianan bahwa "ini juga buminya
Allah” disini (Amerika) juga banyak kok
yang muslim, yang juga sama sama
islam”"

Pembenaran dalam perilaku amoral yang dilakukan oleh $\mathrm{Y}$ sejalan dengan teori yang di kemukakan oleh Bandura (2002) mengenai moral disangeggement atau pelepasan moral, salah satu mekanisme kognitifnya yaitu justifikasi moral, yang berarti bahwa seseorang melakukan tindakan buruk dan pada proses melakukan hal buruk tersebut tampak dibenarkan secara moral. Sejalan dengan teori Bandura, Y sebelum keluar jaringan menjustifikasi atas perilakunya yang amoral, karena menurut subjek yang dilawan adalah orang sepadan. Namun pandangan tersebut sudah tidak dibenarkan oleh subjek lagi, $\mathrm{Y}$ tidak lagi membenarkan aksinya. Perubahan rasionalisasi pada subjek memiliki kemiripan pada penelitian Garfinkel (2009) mengenai perubahan seorang ulama 
yang radikal atau pendeta yang radikal dan penuh prasangka terhadap kelompok lain menjadi pribadi yang moderat dan menerima keragaman. Adanya perubahan tersebut terjadi karena trasformasi personal, Garfinkel menjelaskan, transformasi personal adalah perubahan individual dari suatu kondisi pada satu sisi ekstrim menuju sisi ekstrim yang lain dan berlawanan dengan yang pertama atau dari ranah buruk menjadi ranah yang lebih baik.

Sama halnya dengan Y dalam proses perubahannya, ia mengalami perubahan pandangan secara personal, dalam proses perubahannya ia memiliki pengetahuan yang semakin baik mengenai tentara maupun Amerika, sehingga justifikasi moral ini yang memungkinkan $\mathrm{Y}$ untuk tidak melakukan bom serta tidak mengaggap bahwa Amerika juga bagian dari ciptaan Allah.

\section{b. Penghalusan istilah}

Dari hasil wawancara ada banyak penggunaan istilah yang digunakan didalam kelompok jaringan Y, baik yang dibuat sendiri sesuai periode jaman seperti istilah "Pengantin" tradisi sejak bom Bali 2, "Muhajirin Anshar", "Baiat", "Amaliah" serta hasil dari pemaknaan ayat-ayat Alquran yang dianggap sebagai bentuk menjalankan Syariat Islam. Dari penghalusan istilah ini mengakibatkan $\mathrm{Y}$ bersedia melakukan aksi ekstrim. Berikut pernyataan Y:

Y: "sejak tahun 2000 itu literatur ya saya dapatkan di Alquran "Jihad lah kamu dengan jiwa ragamu” maksudnya dengan harta juga dengan nyawa. Versi saya waktu itu menginterpretasikan ayat ini "Jihadlah dengan Hartamu, berarti jual motor, kemudian dibagi bagikan ke orang yang berjuang begitulah bahasanya waktu itu, ngasi donasi. Misalkan di Jawa dulu waktu itukan masih kotak peduli Poso, peduli Ambon. Itukan bagian dengan "Hartamu", nah sing poin dengan "Jiwamu” kapan? Nyawamu mu kapan??. Maka saya menginterpretasikan seperti "Relawan". Kalo saya matikan berarti nyawaku sudah ku serahkan sebagai Relawan itu"

Y: "Kalo dulu ada namanya medan juang, itu untuk ketika kita rela meninggalkan keluarga itu sudah fisabililah dan siap mati, dan mengorbankan hartanya yah saya jual itu, sudah saya artinya sudah siap pisah dengan dunia”

Setelah keluar dari jaringan penggunaan istilah ataupun penghalusan istilah dalam mengintepretasikan ayatayat dalam Alquran, Y menunjukkan perubahan, seperti dapat dilihat dari ketidaksetujuannya terhadap Jihad Fisabilillah yang megharuskan perang melainkan bisa dalam bentuk mendidik anak istri, membangun rumah, memberi sumbangan/zakat, dan lain sebagainnya. Berikut kutipan;

Y: "Hari ini makna amwal "amwal itu harta yang kami punyai untuk fisabililah ya mendidik anak juga bisa fisabililah, membimbingan istri bagi saya itu sudah fisabililah, (...) kemudian seperti diskusi kemaren, "ini wahana ilmu dan itu fisabilillah jadi saya anggap inilah jalur jalur yang dibenarkan untuk proses menyalurkan harta harta"

Y: "Harta jiwa kita ya bisa kita salurkan dengan pendidikan pondok pesantren, agama, (...), menurut saya itu juga sudah 
fisabilillah, karena kita ingin mencoba meringkan saudara saudara kita yang punya masalah"

Pada subjek Y penggunaan istilah maupun penghalusan istilah merupakan bagian yang tidak terlepaskan dari awal $\mathrm{Y}$ bergabung hingga keberanian dan kesediaannya untuk melakukan aksi ekstrim. Bandura (2002) menjelaskan bahwa seseorang menggunakan suatu bahasa netral secara moral oleh seseorang untuk membuat suatu perilaku buruk menjadi suatu perilaku yang terlihat tidak terlalu buruk, bahkan terlihat baik. Berdasarkan teori ini, $Y$ telah merasionalkan perilaku ekstrimnya melalui penghalusan istilah (euphemistic labeling). Penghalusan istilah yang dilakukan $\mathrm{Y}$ mengakibatkan perilaku ekstrimnya menjadi tampak perilaku yang tidak buruk karena $\mathrm{Y}$ beranggapan hal tersebut dibolehkan dalam Alquran.

Penelitian sebelumnya oleh Gazi (2016) yang menyatakan bahwa ada perbedaan dalam memahami konsep dan penerapan jihad. Perbedaan ini menggambarkan adanya proses deideologisasi jihad. Bagi anggota Jamaah Islamiyah yang masih radikal, jihad adalah tugas abadi sebagai konsekuensi dari keyakinan tentang thoifah manshurah (orang terpilih). Tetapi bagi anggota Jamaah Islamiyah yang mengalami deideologisasi, jihad itu bukan tugas abadi. Jihad tergantung kebutuhan dari sisi tempat dan waktu. Hal ini sejalan dengan dialami oleh $\mathrm{Y}$ yang pernah menjadi anggota Jemaah Islamiyah serta pernah bergabung dalam jaringan Moro Islamic, dimana setelah Y keluar dari jaringan, penghalusan istilah sudah tidak dibenarkan lagi. Y memaknai Jihad Fisabillilah tidak lagi tentang perang, melainkan bisa dengan zakad/menyumbang, bertanggungjawab terhadap istri anak serta keluarga, dll. Perubahan pemaknaan ayat Alquran yang dialami $\mathrm{Y}$ dapat disebabkan karena adanya proses deideologisasi seperti yang disebut oleh Gazi, dimana subjek memahami bahwa Jihad bukan tugas abadi serta memahami jihad dapat dilakukan tergantung kebutuhan seperti di negara berkonflik dapat dilakukan dll.

\section{c. Perbandingan yang menguntungkan}

Kepada subjek sebelum keluar dari jaringan memiliki pandangan bahwa aksi yang kelompoknya perbuat dengan aksi yang dilakukan sekutu Amerika belum seimbang. Aksi yang dilakukan Amerika lebih besar dibandingkan aksi kelompoknya. Membandingkan perilaku tidak etis dengan perilaku etis merupakan bagian dari rasionalisasi atau pembenaran perilaku amoral menjadi moral. Subjek Y menunjukan perilaku-perilaku tersebut, seperti pada kutipan berikut ini; 
Y: "Lah kalo kita masih melihat Amerika dengan bomnya yang begitu dahsyat itu, kalo sampean belum membalas, itu belum imbang sebenarnya. Jadi saya menganggap Amerika harus kita tuntut tetap. Iya lebih besar yang mereka perbuat untuk kami, termasuk membuat kami terusir dan lain sebagainya"

Y: "Ketika terlibat dijaringan itu memang ada semacam desakan desakkan, orang Amerika ini ngebom Irak, Suriah, ngebom Afganistan negara muslim, maka itu harus benci orang bule, yang jelas kristen yang dari Amerika atau termasuk Myanmar ya, orang Budha"

Setelah keluar dari jaringan pandangan $\mathrm{Y}$ mengenai perbandingan aksi antara Amerika dengan aksi dari kelompok jaringan $\mathrm{Y}$ mengalami perubahan. Perubahan-perubahan tersebut ditunjukkan dengan perubahan pandangan terhadap negara Amerika yang semula sangat membenci Amerika, sekarang berpandangan bahwa kebencian terhadap Amerika sudah keluar dari normatif dan juga tidak sepakat adanya perang melawan Amerika yang dilakukan di Indonesia.

Y: "Walaupun benci dengan Amerika, kalo ada kedutaan Amerika di Indonesia, jakarta maupun di surabaya gak dengan serta merta, tapi versi kami waktu itu ada demo, menyalurkan aspirasi tidak suka dengan Amerika kan tersampaikan "oh ternyata kedutaan Amerika di indonesia, jakarta dan surabaya itu sedang didemo untuk menyampaikan aspirasi tidak setuju agresi Amerika ke Afghanistan" itu kan sudah sampai bahasa diplomatik sampai adapun bahasa perangnya ya lakukan perang di Afghanistan dong. Jadi bukan ngebom kedutaannya"

Y: "Kemudian ketika saya balik ke indonesia, "kok isu Amerika dibawa kesini yah" tentang sekutunya Amerikalah, Jepang, Australi, yang ada di bali, (..) Itukan imbas ketika benci Amerika yo tapi kan kebablasan. Jadi ada kalanya ketika itu saya melihat "wah itu udah keluar dari normatif" kita ingin membalas Amerika kok orang sipil dibalas, mestinya tentara amerika yang ngebom itu"

Bandura (2002) menjelaskan bahwa perilaku membandingkan merupakan bagaimana sikap seseorang yang tidak etis akan berbahaya bila dibandingkan dengan sebuah perilaku etis, sehingga membuat sikap aslinya yang muncul dapat diterima. Sejalan dengan teori Bandura, memang sebelum keluar jaringan $\mathrm{Y}$ membandingkan perilaku kelompoknya dengan perilaku Amerika. Dimana Y menganggap pengeboman yang dilakukan Amerika sangat besar dan tidak sebanding dengan kelompok jaringan lakukan. Walaupun demikian sekarang Y memiliki pandangan berbeda, $\mathrm{Y}$ tidak lagi membandingkan kejahatan siapa yang lebih besar, tetapi sekarang lebih memilih dengan cara demo untuk penyampaikan aspirasi keluh kesa terhadap Amerika. Perubahan rasionalisasi ini dapat berkaitan dengan terori Tsang (2002) mengenai situasi dimana seseorang berada dapat mencegah terjadinya rasionalisasi moral untuk melanggar prinsip moral mereka. Y berada di Indonesia yang merupakan bukan negara konflik, sehingga $\mathrm{Y}$ dengan pandangan yang baru lebih memilih jalan demo untuk menyampaikan ketidaksukaannya terhadap Amerika, dibandingkan melakukan perang atau 
melakukan perlawan kekerasan terhadap Amerika.

\section{d. Tidak menghargai atau mendistorsi \\ konsekuensi}

Dari hasil data yang diperoleh, ketika Y masih terlibat dijaringan teroris pengabaian atas konsekuensi serta menggampang sesuatu hal terjadi pada $\mathrm{Y}$, dapat dilihat ketika Y memilih menjadi "relawan" tanpa memikirkan konsekuensi yang akan terjadi, kemudian mengabaikan pondok pesantren dan lebih memilih menyumbang untuk perang yang $\mathrm{Y}$ anggap lebih mulia. Pengabaian ini merupakan bagian dari ketidakatifan regulasi emosi, sehingga $\mathrm{Y}$ merasionalisaskan perilakunya seperti pengabain konsekuensi tersebut sebagai perilaku yang mulia. Berikut kutipan:

Y: "Banyak informasi tentang hancurnya kota itu (Afghanistan), banyak informasi korbannya pengungsi, (..) menjadi alasan kuat untuk membalas, tapi makna membalas ini "aku akan jadi sukarelawan, menjadi pejuang negeri itu.” (...) Waktu itu cita-cita ingin ketemu Osama Bin Laden dan saya akan perang di Afghanistan, itu cita cita dalam hati kecil saya dan itu kuat"

Y: “(...), pondok pesantren ini masih dibawah sementara perang jihad fisabilillah itu diatas saya harus jual motor pun ta kasih pondok, eh eman eman, untuk perang aja lebih mulia, lebih gagah lebih jaya, macem macem lah, seperti itu."

Y: "Tentang mindset "musuh" jadi ketika kita menganggap bahwa musuh nya orang filipin ya harta jiwa nya harus kita korbankan untuk melawan filipin"

Setelah keluar dari jaringan $\mathrm{Y}$ memiliki perubahan rasionalisasi dari yang mengabaikan konsekuensi menjadi lebih berhati-hati dan berpikir panjang, seperti bahwa ia tidak akan dengan sengaja berangkat ke Afganistan maupun Filipin untuk melakukan aksi lagi dengan pertimbangan $\mathrm{Y}$ memiliki keluarga serta sekarang lebih memperhatikan pendidikan di Indonesia dibandingkan memberikan hartanya untuk pendanaan perang.

Y: "Sekarang tidak ada unsur kesengajaan saya berangkat kesana, jadi tetap saya tidak akan pernah berangkat kesana, karna hari ini saya juga ada di Indonesia, (..)tentu ada amalan yang terbaik ketika kita lakukannya disini, (..)"” Y: "Hari ini kan kenyataannya saudara saudara kita pendidikannya juga lemah wes lemah, putus sekolah, (..) Jadi fenomena masalalu dengan sekarang jelas berbeda, kalo mau menyelamatkan kaum muslimin, ini juga bagian dari menyelamatkan kaum muslimin dan juga muslimin jaya dong"

Y: “(..), saya selalu melihat ada konflik, di Indonesia kan gak ada konflik, Ambon pun ada konflik tapi sudah selesai, saya katakan "jangan membawa suriah kesini" tapi kalo kamu mau konflik silahkan kamu kesana, konflik aja disana, saya bilang begitu, gunakan ayat ayat itu disana. Kenapa saya seperti itu karena yang kamu kehendakan itu konflik"

Hal ini sejalan dengan teori moral disangenggetmen (pelepasan moral) oleh Bandura (2002) bahwa salah satu mekanisme kognitif ketidakatifan regulasi emosi yaitu seseorang selalu menggampangkan atau tidak memperdulikan konsekuensi atau resiko dari apa yang telah dilakukan meskipun tarafnya kecil. Salah satu teori yang menjelaskan mengenai faktor yang menyebabkan seseorang mengabaikan 
konsekuensi dari tindakannya adalah Operant-utilitarian theory of criminality, Wilson dan Herrnstein (1998) dalam teori ini menjelaskan mengenai sifat alamiah manusia berkembang oleh karena beberapa interaksi faktor utama, yang salah satunya adalah lingkungan sosial. Faktor lingkungan sosial adalah ketika nilai-nilai sosial diabaikan sehingga individuindividu tidak dapat lagi dikendalikan oleh nilai-nilai tersebut.

Sejalan dengan teori tersebut, $\mathrm{Y}$ sebelum keluar jaringan berada dalam lingkungan sosial yang mengabaikan nilainilai sosial pada umunya, berada pada lingkungan kelompok jaringan membuat Y akhirnya mengabaikan pondok pesantren dan lebih memilih menyumbangkan uangnya untuk mendukung aksi perang yang dianggap lebih mulia, selain itu Y lebih memilih menjadi "relawan" dan mengabaikan konsekuensi yang akan terjadi pada dirinya. Kemudian, Maio \& Haddock (2007) menuliskan para ahli sepakat bahwa sikap dapat berubah karena dinamis dan hasil proses belajar, sesuai dengan teori tersebut setelah Y keluar dari jaringan, Y mengalami perubahan, sikap Y lebih berhati hati dan berpikir panjang dalam mengambil suatu keputusan, hal ini dapat terjadi salah satunya karena adanya proses belajar, belajar dari pengalamannya sewaktu terlibat dalam jaringan hingga mengakibatkan ia masuk penjara.

\section{e. Dehumanisasi}

Pada subjek Y telah mengelompokkan serta menganggap kelompok tertentu sebagai musuh serta berhak untuk dibunuh. Dari hasil data, Y menganggap bahwa tentara, polisi dan densus sebagai musuh yang layak untuk dilawan dan diserang. Y juga menggangap Amerika maupun Myanmar sebagai musuh atau bangsa yang layak untuk diserang serta ada rasa bangga ketika $\mathrm{Y}$ bersama kelompoknya berhasil menembak maupun memukul mundur lawanya (tentara).

Y: "kalo dulu Tentara musuh, polisi bunuh" "Amerika ini ngebom Irak, Suriah, ngebom Afganistan negara muslim, maka itu harus benci orang bule, yang jelas kristen yang dari Amerika atau termasuk Myanmar ya, orang Budha"

Y: "Ya memang secara murni bangga, aku bisa nembak musuh (tentara), imbang teman ku ada yang ketembak 3, kita dapat 8. ranjau kita letakkan kemudian kita tinggal mungkin 2 hari 3 hari lalu blerrrr (..)"

Y: “(..), ayat itu memang kalo bukan kita yang dibunuh, ada ayatnya kita harus membunuh dia, itu ada ayatnya "terbunuh atau dibunuh". "kalo kamu meninggal, kalo kamu luka misalnya, itu sudah dicatat di surga" "kalo kamu tidak ikut kelompokku kamu tidak masuk surga",

Setelah keluar dari jaringan pandangan ekstrim terhadap tentara, densus, Filipina serta Amerika mengalami perubahan rasionalisasi, jika dulu $\mathrm{Y}$ menganggap tentara, densus, Filipina serta Amerika sebagai musuh dan berhak untuk 
dibunuh, namun sekarang terjadi perubahan seperti adanya koordinasi yang baik antara $\mathrm{Y}$ dengan Polisi maupun densus untuk membantu teman-teman teroris agar tidak terlibat lagi dengan kelompok jaringan.

Y: "sekarang saling berkordinasi dengan pihak kepolisian untuk membantu menangani teman-teman yang masih rentan dan masih ingin kembali terlibat, saya dihubungi untuk menenangankan teman-teman semisal yang di solo, semarang itu agar tidak terprovokasi"

Bandura (2002) mengemukakan seseorang yang tidak menggangap orang lain sebagai manusia pada umunya disebut dengan dehumanisasi. Konsep dehumanisasi pada $\mathrm{Y}$ adalah ia menganggap outgrup sebagai "musuh". Ramakrishna (2009) menyatakan dalam konteks Jemaah Islamiyah Indonesia, "musuh jauh adalah Amerika Serikat dan musuh dekat adalah penguasa NKRI selain itu negara kawasan Asia Tenggara seperti Filipina atau Malaysia dianggap musuh dekat". Hal ini sejalan dengan Y sebelum keluar jaringan, ia men-dehumanisasi kelompok tertentu seperti tentara Amerika, tentara Filipina, TNI, densus, serta polisi dan juga kelompok agama yang berbeda, dianggap sebagai kelompok "musuh" dalam artian berhak di bunuh. Setelah tertangkap dan dipenjara $\mathrm{Y}$ mengalami perubahan rasionalisasi didalam penjara, yang semula membenci polisi, namun sekarang saling berkoordinasi untuk membantu mengentaskan jaringan teroris. Pengalaman berinteraksi dengan orang yang berbeda dalam kondisi yang menyenangkan dan penuh persahabatan akan membuka wawasan sempit menjadi lebih terbuka sehingga menerima orang lain dengan baik (Hogg \& Abrams, 1998; Brewer, 2010). Penjara dapat menjadi salah satu sarana berinteraksi dengan banyak orang, sehingga perubahan pun dapat terjadi karena wawasan lebih terbuka dalam artian tidak hanya informasi dari satu arah atau satu kelompok tertentu yang dapat didengarkan, melainkan dari banyak pihak, sehingga akan ada informasi yang lebih baru dan dapat mengurangi penilaian buruk terhadap orang lain atau kelompok tertentu.

\section{f. Menyalahkan orang}

Secara umum Y beranggapan bahwa apa yang terjadi bukanlah kesalahan dari dirinya melainkan menyalahkan lingkungan, densus, tentara, serta Amerika. Hal tersebut dapat dilihat dari bagaimana $\mathrm{Y}$ menyalahkan propaganda yang ia pahami dari buku dan media sosial kemudian juga menyalahkan lingkungan tempat ia berada ketika kembali dari Filipina. Selain itu, Y juga menyalahkan densus dan tentara, karena menembak mati teman temannya yang ia rasa sudah kooperatif dengan negara, serta ketidaksukaannya pada tentara Amerika 
karena membuat konflik di negara Timur Tengah.

Y: "satu sisi ya aku menyalahkan lingkungan "kenapa aku hidup disana terus" coba aku setelah 3 bulan disana terus pulang ke Surabaya (..)"

Y: "Termasuk tentara Indonesia (..), bukan Negara ini eh sipilnya Indonesia, tapi tentara Indonesia termasuk Polisi, Densus, Jadi yah penangkap sehari, besok meninggal, (..), terus termasuk ketika saya ditangkap, Kusiono ditangkap misalnya, ketika dia sholat mahgrib, besoknya sudah meninggal dunia. Ngelawannya pakai apa saya bilang seperti itu (..) Itu kemungkinan Densus yang salah."

Y: "Itu karena secara global mba, jadi hampir Negara Timur Tengah ketika berkonflik itu karena Amerika datang karena Asing datang gitu aja, (..)"

Setelah keluar dari kelompok jaringan, $\mathrm{Y}$ memiliki perubahan pandangan atas siapa yang patut disalahkan. Y tidak lagi menyalahkan sepenuhnya pada lingkungan atau propaganda buku-buku serta informasi dari media sosial yang dia terima, tetapi $\mathrm{Y}$ juga merefeleksikan dirinya atas perilaku amoralnya. Selain itu Y juga besyukur karena ditangkap, tidak lagi menyalahkan polisi maupun densus, serta mengenai Amerika sekarang $\mathrm{Y}$ bahkan bersedia untuk mengantar ketika kedatangan tamu dari Amerika atau tamu luar negeri.

Y: "mungkin karena waktu itu aku tidak berpikir yang sehat karena aku menerimanya ya informasi itu kalo ini ya ini, tanpa ini pembandingnya, ini pembanding ini, gak tau”

Y: “(...) ketika ketemu polisi dan diforum juga saya bilang"saya bersyukur ditangkap, karena dengan saya di tangkap saya tidak bisa melanjutkan pengeboman,"
Y: "Begini mba, jadi orang membenci Amerika harus ke knowledge, ada ilmunya, misalnya aku tau WTC "kenapa sih wtc di bom dan kenapa ada kebencian internasional?" (..) kalo saya datang ke Amerika jangan-jangan yang saya terima tentang Amerika negatif aja, yang positifnya gak keliatan. Makanya ketika saya ada ketemuan keturunan jawa didunia, saya ketemu ibu-ibu yang sudah 40 tahun di Amerika. Dari situ saya bisa menilai "ibu ini muslim hidup di amerika 40 tahun ik juga gak ada apa-apa dengan dia" itu kan sisi lain positif tentang Amerika, (..)

$\begin{array}{ccc}\text { Seseorang } & \text { yang } & \text { telah } \\ \text { merasionalisasikan } & \text { perilakunya } & \text { dari }\end{array}$ amoral menjadi moral akan menempatkan kesalahan bukan pada diri sendiri atas perilaku amoral yang dilakukannya, Bandura (2002) menyebut hal tersebut dengan blaming the victim bahwa seseorang yang bersikap diri dengan menempatkan kesalahan atas perilaku yang dia lakukan kepada orang lain. Sama seperti yang Y lakukan sebelum keluar dari jaringan, ia menyalahkan polisi, densus hingga Amerika atas perilaku amoralnya. Namun perubahan pandangan dalam menyalahkan orang lain, seperti salah satunya pengalaman $\mathrm{Y}$ bertemu dengan seorang ibu keturunan jawa dan beragama muslim yang tinggal di Amerika sudah 40 tahun, membuat $\mathrm{Y}$ mengalami perubahan pandangan terhadap Amerika. Informasi negatif yang Y terima selama bergabung dengan jaringan menutup bahkan menolak hal-hal positif tentang Amerika maupun tentang 
densus, yang mengakibatkan kebencian bahkan menyalahkan lingkungan, densus, maupun Amerika atas perilaku amoral yang dilakukannya. Sejalan dengan teori Brown (2010), Penolakan terhadap outgroup lebih disebabkan karena kurang informasi dan pengetahuan mengenai orang lain yang berbeda sehingga pikiran dan perasaan lebih didominasi oleh prasangka.

\section{Hal-hal Pendorong Perubahan}

\section{Rasionalisasi Moral}

Tsang (2002) menyebutkan bahwa faktor situasi dan psikologis merupakan faktor yang dapat mencegah seseorang menyadari perilaku yang melanggar prinsip standar moral mereka. Ketika rasionalisasi moral berinteraksi dengan variabel situasional tertentu, kejahatan ekstrem dapat terjadi. Situasi peran juga berpengaruh seperti yang dikemukakan oleh Blumenthal (1999) bahwa fokus pada peran adalah kontributor penting untuk perilaku tidak bermoral. Jika peran yang diberikan mencakup perilaku agresif atau tidak etis, individu dapat melakukan perilaku itu tanpa menyadari bahwa itu melanggar prinsip moral mereka.

Horgan (2009), merupakan seorang peneliti yang fokus menelaah dan meneliti dibidang psikologi terorisme salah satunya berkaitan dengan deradikalisasi. Penelitian Horgan pada sejumlah mantan ekstrimis radikal keagamaan di Timur Tengah, menyimpulkan bahwa perubahan dari cara pandang radikal menuju cara pandang keagamaan moderat dipengaruhi oleh beberapa hal yaitu faktor personal seperti disilusi ideologi, stress dan bornout, serta faktor fisik seperti pemenjaraan dan perubahan peran.

Berkaitan dengan hasil penelitian Horgan (2009) beberapa faktor pendorong perubahan yang disebutkan Horgan memiliki perbedaan dalam penelitian yang saya lakukan yaitu adanya hal-hal pendorong lainnya sehingga terjadi perubahan seperti adanya pengalaman, hingga adanya peran personal.

\section{a. Pengalaman}

Penjara menjadi pengalaman yang cukup berkontribusi penting terhadap perubahan yang $\mathrm{Y}$ alami. Pengalaman hidup di penjara yang penuh dinamika memberikan pelajaran berharga bagi subyek. Interaksi dengan banyak orang serta merenungkan perbuatannya, dan akhirnya memilih untuk berperilaku baik terhadap negara, mengikuti upacara, mengikuti kegiatan-kegiatan didalam penjara dan tidak melawan petugas.

Y: “(..)bagaimana yah kejadian kita kok begini? Apa kita ini melawan Negara? Sebaiknya kita ikuti aturan Negara, dihukum yah disidang”. Sidang itu sudah mulai sadar sebenarnya saat di penjara berempat, sadar apasih, masuk upacara, saya didalam penjara masuk upacara (...) Makanya saya merintis dengan berempat itu "ayok kita sama sama berperilakuan 
yang baik, gak usah melawan petugas dan mengancam petugas, terus kalo ada workshop pendidikan dipenjara atau bimbangan yah kita ikut",

Gazi (2016), menyebutkan bahwa pengalaman bisa menjadi sumber belajar karena merupakan dasar utama dalam learning by doing atau experential learning. Pengalaman bukan hanya menyangkut apa yang kita lakukan tetapi juga menyangkut apa yang kita pikirkan dan kita rasakan. Maka, para ahli psikologi sepakat bahwa dimensi dari pengalaman itu meliputi pengalaman mengerjakan, pengalaman memikirkan, dan pengalaman merasakan. Semua itu akan menjadi sumber pembelajaran jika individu bisa menyerap inti dari pengalaman tersebut. Sejalan dengan teori tersebut pengalaman berada di penjara membuat $\mathrm{Y}$ merenungkan perilakunya, berdiskusi bersama teman, sampai pada keputusan untuk berubah dan memilih berperilaku baik.

\section{b. Peran keluarga}

Y menjelaskan ketika ia dalam proses keluar dari jaringan, peran keluarga atau parenting memiliki peran sangat penting bagi dirinya. Mengingat salah satu faktor awal keterlibatan $\mathrm{Y}$ dengan kelompok jaringan yaitu banyak hal yang harus ditutupi, sehingga komunikasi dengan keluarga menjadi tidak baik serta mengakibatkan Y tumbuh dengan ideologi yang keliru. Namun selama di penjara, kunjungan dari keluarga maupun kerabatnya memberikan kekuatan baru serta pandangan baru bagi $\mathrm{Y}$, ia merasa lebih diterima dan merasakan kasih sayang dari keluarga.

Y:(..) makna keluarga bahagia terus lebih fer, kemudian bisa lebih care dengan keluarga, kemudian bisa menjaga keluarga, nasehati keluarga, itu yang versi saya yang lebih plong, kalo tadi "jangan ceritakan ajaran kamu ke orang lain”, serba dibatasi.

Y: "anu ya, tolong mas y, eh adekku ini titip ya di Semarang, ikut diawasi, ikut dijaga”. Disitu peran keluarga parenting makna parenting iya bener juga yah"

Vangelisti (2004), menjelaskan komunikasi dukungan sosial dalam keluarga sebagai komunikasi yang mampu membuat individu di dalamnya merasa nyaman, diperhatikan, dan dipedulikan. Perasaan ini dirasakan oleh subjek, mendapatkan kunjungan dari keluarga, serta kerabat membuat $\mathrm{Y}$ merasa disayangi, diterima, dan dipedulikan. Selain itu dari perlakuan tersebut menurut West dan Turner (2010), individu akan mempelajari dirinya melalui bagaimana orang lain memperlakukan, melihat, dan memaknai individu tersebut. Dalam artian bahwa perhatian keluarga maupun kerabat atau peran keluarga dalam perubahan rasionalisasi pada mantan narapidana teroris memiliki andil penting, karena melalui keluarga mereka dapat belajar bagaimana seseorang memperlakukannya 
serta menerimanya. Sehingga hal ini dapat memperbaharui pemahaman yang lama ketika masih terlibat dengan jaringan tentang batasan untuk berkomunikasi dengan keluarga karna banyak hal yang harus ditutupi.

\section{c. Memiliki kesibukan/ konsentrasi usaha}

Salah satu pendorong Y membuatnya memilih untuk tidak terlibat lagi dengan jaringan yaitu dengan adanya kesibukan atau konsetrasi yang berbeda dari sebelumnya. Hal ini dapat dilihat $\mathrm{Y}$ memiliki konsentrasi usaha, melalui usaha ini Y dapat bertemu dengan banyak orang sehingga terjalin interaksi, selain itu membuat Y jauh dari intimidasi.

Y: “(...) menguatkan saya untuk tidak
kembali sampai hari ini, punya
konsentrasi usaha, (..)dimana saya
berinteraksi dengan banyak orang,(..)”
Y: "kemudian usaha usaha itu ternyata
ketika saya berusaha pun normatif. Saya
jual beli ikan bakar misalnya,(.) dapat
uang secara normal, jauh dari
intimidasi."

\section{d. Peran Agama}

Hal pendorong lainnya yaitu adanya peran agama. Melalui buku-buku ulama Y mendapatkan pencerahan-pencerahan. Y merefleksikan perilakunya seperti merefleksikan aksi-aksi yang sudah $\mathrm{Y}$ lakukan bersama kelompoknya apakah menegakkan Islam, atau sebaliknya, apakah hanya dengan perang untuk membela islam atau Jihad. Buku-buku ulama yang $\mathrm{Y}$ baca membuat $\mathrm{Y}$ semakin berpikiran terbuka bahwa menjalankan Jihad tidak selalu harus perang, melainkan dengan berbuat amal baik, menyumbangkan ke pondok-pondok pesantren, panti asuhan, membangun rumah ibadah, bertanggungjawab terhadap keluarga juga merupakan menegakkan Islam jaya.

Y: “Sebenarnya kalo masalah keagaman
saya lebih sering baca dibuku buku,
(...),lebih sering baca buku buku yang
sifatnya pencerahan, menjadi penggerak
tapi tidak merusak keluarga, silsilah, dan
terutama citra Islam. jadi saya
menganggap apa yang diputuskan ulama
ulama dalam buku yang saya baca yang
paska bebas itu banyak pencerahan”"
"(...)berangsur angsur bisa pulih dari
pemahaman yang hanya sepintas dan
sifatnya perang” (..) ini juga bagian dari
menyelamatkan kaum muslimin. Kan juga
kita mau perang biar tegak muslimin jaya,
nah ini juga muslimin jaya dong”

\section{e. Keinginan hidup bermakna}

Pada subjek, ia memiliki keinginan untuk hidup bermakna. Dapat dilihat dari keinginannya untuk mengentaskan terorisme, dengan cara melakukan dialog ataupun sharing. Kemudian ia juga mengatakan bahwa pengalamannya sebagai experiennya untuk menjelaskan pada anak-anak. Berikut kutipan percakapan:

Y: "saya hari ini punya PR yang banyak, saudara saudara saya kena pengaruh yang negatif, pengen kita ajak diskusi dialog kita luruskan di Indonesia, dan itu bagi saya cukup bagus untuk, kalo berhasil yah sodara sodara kita juga bisa mengentaskan dari pemahaman negatif dari pengaruh luar negeri"

Y: "(...)Mudah mudahan ketika nanti dipenjara, kemudian kita bisa sharing, gitu aja mba, meluruskan pemahaman. Jadi tidak lebih dari itu, karena perkara 
masa lalu pengalaman yang banyak itu ya menjadi experien saya lah bisa menjelaskan ke anak anak"

Di dalam psikologi, perasaan diterima oleh orang lain adalah kebutuhan dasar yang sangat penting karena dapat meningkatkan self-esteem seseorang dalam kehidupan sosial. Bahkan Darajat (dalam Gazi, 2016) menganggapnya sebagai syarat inti sehat mental pada seseorang. Dengan kata lain, jika seseorang telah merasa diterima di dalam kehidupan sosial yang nyata maka harga dirinya akan meningkat dan ia akan benarbenar merasa ada atau eksis sebagai individu dan bagian dari kehidupan sosial. Hal tersebut dialami oleh Y, mendapatkan dukungan serta merasa diterima membuat Y merasa ada dan eksis ditengah tengah masyarakat. Keberhasilan Y hidup ditengah-tengah masyarakat membuanya ingin membantu orang lain khususnya teroris untuk mengentaskan pemahaman negatif agar tidak kembali terlibat kelompok jaringan.

\section{f. Peran personal}

Sejalan dengan teori tersebut, dari hasil wanwancara Y secara pribadi berkeinginan memperbaiki diri, karena selama ini dihadapan jaringan maupun dihadapan masyarakat dipandang negatif seperti dihadapan masyarakat Y dianggap sebagai kelompok teroris dan tidak dapat disembuhkan. Hal tersebut membuat Y semakin ingin menyakinkan bahwa ia bisa sembuh.

Y: “(...) dari dalam diri saya sendiri ada muncul semacam keinginan ingin memperbaiki diri mba, karena selama ini dihapan jaringan maupun dihadapan masyarakat kan negatif. Pertama dihadapan masyarakat bahwa ini kelompok teroris dan ini tidak bisa sembuh. Saya ingin meyakinkan bahwa saya bisa sembuh"

Bandura (2002), mengemukakan bahwa regulasi moral dapat diaktifkan dan tidak diaktifkan sesuai keinginan. Dalam kasus ini, keinginan untuk berubah timbul dalam diri subjek karena adanya perasaan tidak nyaman atas penilaian negatif yang diberikan oleh masyarakat. Selain itu subjek ingin membukatikan bahwa ia bisa sembuh.

\section{KESIMPULAN}

Berdasarkan hasil penelitian dapat disimpulkan bahwa, Perubahan rasionalisasi dapat terjadi pada setiap individu yang memiliki keinginan untuk berubah. Hal tersebut dapat terjadi karena adanya tranformasi personal, deideologisasi pada pemahaman yang radikal sehingga pemahaman Jihad Fisabilillah tidak bersifat abadi mengenai perang, situasi dimana seseorang itu berada juga dapat berpengaruh dalam perubahan rasionalisasinya, kemudian kebenaran bahwa manusia adalah makhluk yang dinamis sehingga sikap maupun pola pikir pun dapat mengalami 
perubahan, pengalaman interaksi dengan banyak orang serta keterbukaan dalam mernerima informasi-informasi. Adapun Hal-hal pendorong perubahan rasionalisasi yang didapatkan dari analisis data yaitu pengalaman, hingga adanya peran personal.

\section{SARAN}

Penelitian ini tidak terlepas dengan kekurangan, sehingga untuk penelitian selanjutnya diharapkan dapat melakukan penelitian dengan melibatkan banyak partisipan, sehingga perubahan rasionalisasi dari masing-masing partisipan dapat dilihat lebih luas atau beragam. Penelitian selanjutnya juga dapat menggunakan dengan metode selain kualitatif. Bisa dengan kuantitatif maupun membentuk kelompok eksperimen membedakan kelompok JI dan Kelompok Isis.

\section{DAFTAR PUSTAKA}

Bandura, A. 1991. Self-regulation of motivation through anticipatory and self-regulatory mechanism. In R. A. Dienstbier (Ed.), Perspectives on motivation: Nebraska symposium on motivation (Vol. 38, pp. 69-164). Lincoln: University of Nebraska press.

Bandura, Caprara, Barbaranelli C, Pastorelli C, Regalia C. 2001. Sociocognitive self-regulatory mechanisms governing transgressive behavior. Journal of Personality Social Psychology, 80 (1), 124-35.
Bandura, Caprara, Barbaranelli C, Pastorelli C. 1996. Mechanisms of moral disengagement in the exercis of moral agency. Journal of Personality Social Psychology, 71 (2), 364-374.

Brown, Rupert, and Sam Gaertner. 2003. Handbook of Psychology: Intergroup Processes. Malden MA: Blackwell Publishing.

Garfinkel, R. 2007. Personal transformations: moving from violence to peace. Washington DC: United States Institute of Peace.

Galtung, J. 1987. On the causes of terrorism and their removal. New Jersey: Department of Politics, University of Princeton.

Gazi. 2016. Personal tranformation: from criminality to piety. Vol. 39, No. 2. UIN Jakarta.

Golose, P. R. 2009. Deradikalisasi terorisme, humanis, soul approach dan menyentuh akar rumput, Jakarta: Yayasan Pengembangan Kajian Ilmu Kepolisian.

Hogg, M. A. 2001. A social identity theory of leadership. Personality and Social Psychology Review , Vol. 5, No. 3, 184-200

Horgan, John. 2009. Walking away from terrorism: Accounts of disengagement from radical and extrimist movements. Oxon: Routledge.

Maio, G. R., \& Haddock, G. 2007. Attitude Change. In A. W. Kruglanski, \& E. T. Higgins, Social Psychology: Handbook of Basic Process (pp. 565-586). New York: The Guilford Press.

Milles dan Huberman. 1992. Analisis Data Kualitatif. Jakarta: Universitas Indonesia. 
Poerwandari, E K. 2007. Pendekatan kualitatif untuk penelitian perilaku manusia. Depok: LPSP3.

Ramakrishna, Kumar and Seng Tan, See. 2003. After Bali: the threat of terrorism in Southeast Asia.
Tsang, J. 2002. Moral rationalization and the intergration of situational factors and psychological processes in immoral behavior. Review of General Psychology, 6, 1, 25-50. Doi: 10.1037///10892680.6.1.25 